Terakreditasi: SK No.: 60/E/KPT/2016

Website : http://ejournal.undip.ac.id/index.php/reaktor/

Reaktor, Vol. 17 No. 1, Maret Tahun 2017, Hal. 9-16

\title{
Peningkatan Unjuk Kerja Katalisator Zeolit Alam Bayah pada Reaksi Ketalisasi Gliserol
}

\author{
Nuryoto $^{1,2, *)}$, Hary Sulistyo²), Wahyudi Budi Sediawan ${ }^{2)}$, dan Indra Perdana ${ }^{2)}$ \\ 1) Jurusan Teknik Kimia Fakultas Teknik, Universitas Sultan Ageng Tirtayasa \\ Jl. Raya Jendral Sudirman Km. 3 Cilegon, Banten, Indonesia \\ ${ }^{2)}$ Departemen Teknik Kimia Fakultas Teknik, Universitas Gadjah Mada \\ Jl. Grafika No.2 Kampus UGM, Yogyakarta, Indonesia 55281 Telp. (+62274) 561176 \\ ${ }^{*}$ Penulis korespondensi: nuryoto15@gmail.com
}

\begin{abstract}
IMPROVED PERFORMANCE OF BAYAH NATURAL ZEOLITE AS CATALYST ON REACTION OF GLYCEROL KETALIZATION. The catalyst has an important role for the rates of chemical reactions accelerating in orde to achieve the target product of reaction. Reactants mass transfer to the active sites of the catalyst is oftenbe anobstacle to reaching of this purpose, so that the catalyst performance becomes less than the maximum. The objective of this research was to observe how much effected the diameter size catalyst, stirring speed, and catalyst concentration in order to improved performance of Bayah natural zeolite catalyst on glycerol ketalization reaction based on glycerol conversion. The experiments were performed using a batch reactor, reaction temperature of $50^{\circ} \mathrm{C}$, reactant ratio of $6: 1 \mathrm{~mol}$ of acetone $/ \mathrm{mol}$ of glycerol, reaction time of 90 minutes, diameter size catalyst from $-18+25$ until $-60+70$ mesh, catalyst concentration of $0-11 \%$ mass of glycerol, and stirring speed of 200-800 rpm. The results showed that the best conditions obtained at the diameter size catalyst of $-40+45$ mesh, catalyst concentration of $9 \%$ mass of glycerol, and stirring speed of 600 rpm by glycerol conversion reached of $60.92 \%$.
\end{abstract}

Keywords: glycerol; ketalization; performance; natural zeolite

\begin{abstract}
Abstrak
Katalisator mempunyai peranan penting dalam mempercepat laju reaksi kimia untuk mencapai target produk reaksi yang diinginkan. Perpindahan massa reaktan ke sisi aktif katalisator seringkali menjadi kendala dalam mencapaimaksud tersebut, sehingga unjuk kerja katalisator menjadi kurang maksimal. Penelitian ini bertujuan untuk melakukan observasi seberapa besar pengaruh ukuran diameter katalisator, kecepatan pengadukan, dan konsentrasi katalisator dalam rangka meningkatkan unjuk kinerja katalisator zeolit alam Bayah pada reaksi ketalisasi gliserol berbasis konversi gliserol yang dihasilkan. Percobaan dilakukan dengan menggunakan reaktor batch, suhu reaksi $50^{\circ} \mathrm{C}$, perbandingan pereaksi 6:1 mol aseton/mol gliserol,waktu reaksi 90 menit, ukuran diameter katalisator -18+25 sampai -60+70 mesh, konsentrasi katalisator 0-11\% massa gliserol, dan kecepatan pengadukan 200-800 rpm. Hasil percobaan menunjukkan bahwa kondisi terbaik diperoleh pada ukuran diameter katalisator -40+45 mesh, konsentrasi katalisator 9\% massa gliserol, dan kecepatan pengadukan 600 rpm dengan konversi gliserol mencapai 60,92\%.
\end{abstract}

Kata kunci: gliserol; ketalisasi; unjuk kerja; zeolit alam 
How to Cite This Article: Nuryoto, Sulistyo, H., Sediawan, W.B., dan Perdana, I., (2017), Peningkatan Unjuk Kerja Katalisator Zeolit Alam Bayah pada Reaksi Ketalisasi Gliserol, Reaktor, 17(1), 9-16, http://dx.doi.org/10.14710/reaktor.17.1.9-16

\section{PENDAHULUAN}

Kajian penggunaan katalisator padat pada saat ini berkembang cukup pesat (Nanda dkk., 2014; Esteban dkk., 2015), hal ini disebabkan katalisator padat cenderung lebih mudah dipisahkan secara mekanis pada unit separasi dibandingkan katalisator cair. Keuntungan yang lain adalah mampu mereduksi dan mengeliminasi korosi yang muncul pada peralatan proses reaksi (Kolah dkk., 2008). Indonesia mempunyai sumber daya alam berupa zeolit yang belum termanfaatkan secara maksimal baik untuk proses kimia maupun proses fisika. Indonesia mempunyai cadangan zeolit alam yang sangat besar, di Bayah-Banten saja cadangan zeolit alamnya mencapai 123 juta ton (Murpik, 2010). Zeolit alam Bayah sebagian besar merupakan zeolit alam jenis mordenit, dengan kandungan rerata adalah modernit sebesar $59,26 \%$ dan klinoptilolit sebesar $40,74 \%$. Jenis mordenit lebih cocok digunakan sebagai katalisator dibandingkan jenis klinoptilolit, karena zeolit mordenit mempunyai rasio $\mathrm{SiO}_{2} / \mathrm{Al}_{2} \mathrm{O}_{3}$ yang lebih besar dibandingkan jenis klinoptilolit, sehingga lebih hidrofobik (Suminta dan Las, 2006). Hasil karakterisasi terhadap zeolit alam Bayah, Tasikmalaya, dan Lampung melalui uji X-Ray Fluorescence (XRF), mengindikasikan bahwa kandungan Si dan Al pada zeolit alam Bayah lebih tinggi dibandingkan dengan zeolit Lampung dan Tasikmalaya (Ginting dkk., 2007). Hasil analisis XRF berturut-turut adalah 91,55; 76,29; dan 67,28\% untuk $\mathrm{Si}$, dan 5,43; 5,48; dan 4,57\% untuk kandungan Al. Dari ketiga zeolit tersebut, zeolit alam Bayah mempunyai kandungan Si/Al lebih baik dibandingkan zeolit Lampung maupun Tasikmalaya. Hasil studi awal penggunaan zeolit alam Bayah sebagai katalisator oleh Nuryoto dkk. (2015) pada reaksi ketalisasi gliserol dengan aseton mampu mengkonversi gliserol sebesar 57,89\%. Hasil tersebut merupakan hasil permulaan yang cukup baik, dan dimungkinkan dapat ditingkatkan lagi dengan melakukan rekayasa proses agar unjuk kerja dari katalisator zeolit alam Bayah lebih maksimal. Secara sederhana mekanisme reaksi ketalisasi gliserol dan aseton dengan katalisator zeolit menurut Manjunathan dkk. (2014) dapat dilihat pada Gambar 1.

Mekanisme pembentukan solketal pada Gambar 1 mempunyai 4 step. Pada step 1 aseton terprotonasi oleh $\mathrm{H}^{+}$dari katalisator membentuk karbokation. Hidroksi gliserol pada bagian ujung ikatannya menyerang karbokation yang terbentuk menghasilkan hemiasetal (step 2). Ion $\mathrm{H}^{+}$pada zeolit memprotonasi kembali hemiasetal, sehingga terbentuk karbonil group baru yang akan diserang lagi oleh hidroksi gliserol (step 3). Pada step 4, jika yang menyerang hidroksi gliserol pada ikatan bagian tengah maka terbentuk solketal (2,2-dimethyl-1,3-dioxane-4 methanol), namun jika yang menyerang hidroksi gliserol bagian pangkal akan terbentuk asetal (2,2dimethyl-1,3-dioxane-5-ol). Pelepasan air sebagai produk samping terjadi pada step 4 yaitu bersamaan dengan terbentuknya solketal dan asetal.

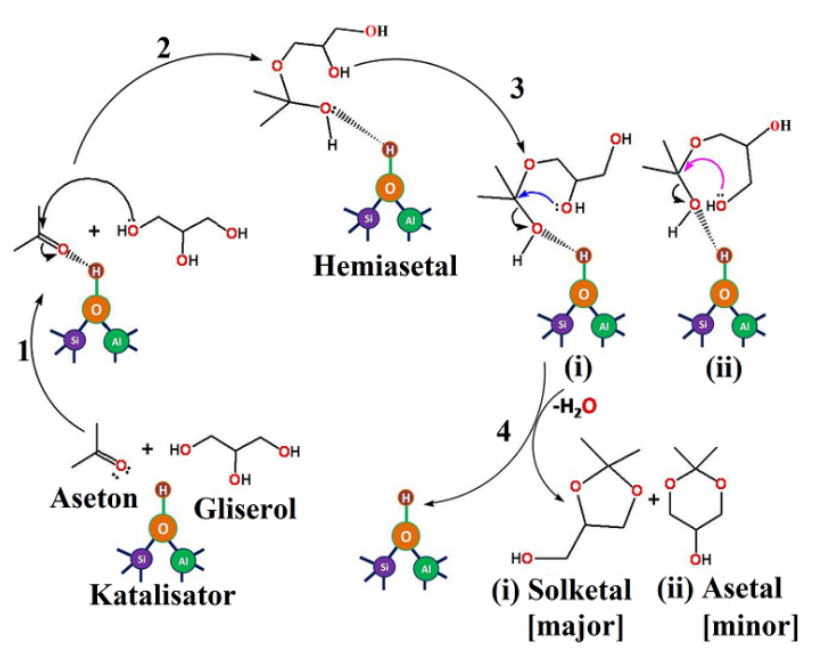

Gambar 1. Mekanisme reaksi ketalisasi gliserol dengan aseton menggunakan katalisator zeolit

Rekayasa proses dalam rangka meningkatkan unjuk kerja dari zeolit alam Bayah agar mampu menghasilkan konversi gliserol yang lebih tinggi lagi yaitu dengan cara meningkatkan kecepatan pengadukan (Liu dan Tang, 2001; Nanda dkk., 2014), ukuran diameter katalisator (Nuryoto dkk., 2012), dan konsentrasi katalisator (Mallesham dkk., 2014; Reddy dkk., 2011). Hal ini dilakukan agar laju transfer massa reaktan dari badan cairan ke permukaan luar katalisator dan dari permukaan luar katalisator ke sisi aktif katalisator mengalami peningkatan, sehingga akan diikuti dengan peningkatan kontak antar reaktan pada sisi aktif katalisator. Hasil percobaan Liu dan Tang (2001) pada reaksi esterifikasi asam propionat dan n-butanol dan Nanda dkk. (2014) pada pembuatan solketal menunjukan bahwa peningkatan kecepatan pengadukan berdampak baik pada konversi reaktan yang hasilkan. Konversi asam propionat pada kecepatan pengadukan $400 \mathrm{rpm}$ adalah $42 \%$ dan menjadi $47 \%$ pada kecepatan pengadukan $1000 \mathrm{rpm}$ (Liu dan Tang, 2001). Pada penelitian Nanda dkk. (2014) konversi gliserol meningkat dari 58\% pada kecepatan pengadukan $400 \mathrm{rpm}$ dan $60 \%$ pada kecepatan pengadukan $1100 \mathrm{rpm}$. Pada investigasi yang lain, Nuryoto dkk. (2012) melakukanuji coba pengaruh ukuran diameter katalisator pada sintesis gliserol karbonat menggunakan katalisator indion 225 Na. Hasil penelitian menunjukkan kecenderungan bahwa semakin kecil ukuran diameter katalisator yang digunakan, diikuti dengan peningkatan konversi gliserol yang dihasilkan. Konversi gliserol untuk 
ukuran diameter katalisator 0,$100 ; 0,046$; dan 0,065 cm masing-masing adalah 22,16; 23,23; dan 25,20\%. Jadi peningkatan kecepatan pengadukan dan memperkecil ukuran katalisator akan mampu meningkatkan kinerja dari katalisator yang digunakan.

Peningkatan kinerja katalisator selain dengan cara meningkatkan kecepatan pengadukan dan memperkecil ukuran katalisator, dapat juga dilakukan dengan cara meningkatkan konsentrasi katalisator dalam sistem reaksi (Mallesham dkk., 2014; Reddy dkk., 2011). Pada dasarnya sisi aktif suatu katalisator sudah tertentu sesuai karakteristik yang dimiliki katalisator tersebut. Tetapi dengan meningkatkan konsentrasi katalisator ke dalam sistem reaksi, maka secara total akan meningkatkan jumlah sisi aktif dari katalisator yang nantinya ikut berperan aktif dalam memprotonasi reaktan menjadi produk. Hasil uji coba dampak konsentrasi katalisator pada sintesis solketal oleh Mallesham dkk. (2014) yang dilakukan menggunakan katalisator $\mathrm{SnO}_{2}$ pada rentang konsentrasi katalisator 1-7\% massa gliserol, berhasil meningkatkan konversi gliserol dari 44\% pada katalisator $1 \%$ massa gliserol menjadi $91 \%$ pada konsentrasi katalisator 7\%. Pada percobaan sejenis, Reddy dkk. (2011) menggunakan katalisator zirkonia, konversi gliserol yang dihasilkan meningkat dari $76 \%$ pada konsentrasi katalisator $1 \%$ massa gliserol menjadi $98 \%$ pada konsentrasi katalisator 5\% massa gliserol.

Penelitian ini bertujuan untuk melakukan observasi seberapa besar pengaruh ukuran diameter katalisator, kecepatan pengadukan, dan konsentrasi katalisator dalam rangka meningkatkan unjuk kinerja katalisator zeolit alam Bayah pada reaksi ketalisasi gliserol berbasis konversi gliserol yang dihasilkan.

\section{BAHAN DAN METODE}

\section{Bahan dan Alat Penelitian}

Bahan utama yang diperlukan pada percobaan iniadalah zeolit alam modernit Bayah (ZAB)Indonesia yang belum dan telah dilakukan perlakuan awal dengan pengasaman menggunakan asam sulfat 6 $\mathrm{N} \mathrm{H}_{2} \mathrm{SO}_{4}$ (Merck) dan pemanasan $200^{\circ} \mathrm{C}$ (mengacu pada penelitian Nuryoto dkk., 2015 dan Nuryoto dkk., 2016), gliserol $\left(\mathrm{C}_{3} \mathrm{H}_{5}(\mathrm{OH})_{3}\right)$ teknis dengan kadar $86,21 \%$, dan aseton $\left(\mathrm{C}_{3} \mathrm{H}_{6} \mathrm{O}\right)$ dari Mallinckodt Chemical dengan kadar 95,70\%.

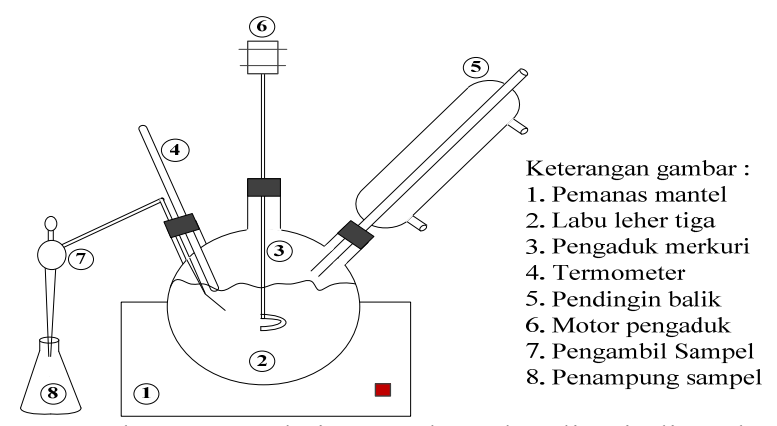

Gambar 2. Rangkaian peralatan ketalisasi gliserol dengan aseton
Reaktor yang digunakan berupa reaktor batch yang terdiri dari pemanas mantel, labu leher tiga, pengaduk mercuri, termometer, pendingin balik, motor pengaduk, pengambil sampel, dan penampung sampelseperti yang tersaji pada Gambar 2.

\section{Prosedur Perlakuan Awal Zeolit Alam Bayah (ZAB)}

Prosedur perlakuan awal mengacu pada penelitian sebelumnya (Nuryoto dkk., 2015; Nuryoto dkk., 2016), yaitu ZAB yang berukuran besar dihancurkan menjadi ukuran yang kecil-kecil melalui proses grinding, selanjutnya zeolit diayak untuk mendapatkan ukuran diameter katalisator yang diinginkan (-18+25 sampai -60+70 mesh). Zeolit hasil pengayakan dilakukan pengasaman menggunakan asam sulfat $\left(\mathrm{H}_{2} \mathrm{SO}_{4}\right)$ dengan perbandingan 10 gram zeolit alam Bayah/100 ml larutan asam sulfat dengan konsentrasi $6 \mathrm{~N}$ (dibuat dengan melarutkan asam sulfat $95-97 \%$ berat Merck dalam air), suhu pengasaman $110^{\circ} \mathrm{C}$, dan waktu pengasaman selama 2 jam. Zeolit yang telah dilakukan pengasaman, dibilas dengan akuades 4 kali dan ditiriskan. Untuk menghilangkan air yang terdapat pada alur-alur di dalam zeolit, maka zeolit dikeringkan dalam oven pada suhu $200^{\circ} \mathrm{C}$ dengan waktu pengeringan selama 2 jam. Zeolit yang telah dikeringkan, kemudian didinginkan sampai suhu kamar untuk dilakukan analisis kekuatan asam.

\section{Prosedur Reaksi}

Gliserol dan aseton dengan volume yang telah ditentukan sesuai dengan perbandingan pereaksi (6:1 mol aseton/mol gliserol), dipanaskan sampai suhu $50^{\circ} \mathrm{C}$, kemudian dimasukan ke dalam reaktor dan dilakukan pengadukan (200-800 rpm). Pada saat larutan telah tercampur homogen, dilakukan pengambilan sampel untuk dilakukan analisis gliserol awal $\left(\mathrm{G}_{\mathrm{o}}\right)$ menggunakan titrasi iodometri. Katalisator dengan ukuran diameter katalisator $(-18+25$ sampai $-60+70$ mesh) dan konsentrasi katalisator tertentu (0$11 \%$ massa gliserol), selanjutnya dimasukkan ke dalam reaktor. Ketika reaksi telah berjalan 90 menit, maka reaksi dihentikan dan bersamaan dengan itu dilakukan pengambilan sampel untuk dianalisis gliserol sisa $\left(\mathrm{G}_{\mathrm{s}}\right)$.

\section{Metode Analisis \\ Analisis kekuatan asam ZAB}

Untuk mengetahui kekuatan asam katalisator hasil perlakuan awal dilakukan menggunakan Temperature Programmed Desorption (TPD) ammonia jenis ChemiSoft TPx V1.02. Sampel yang diperlukan untuk analisis TPD ammonia ini sebanyak 0,1 gram baik ZAB segar (tanpa perlakuan awal) maupun $\mathrm{ZAB}$ dengan perlakuan awal (pengasaman 6 $\mathrm{N} \mathrm{H}_{2} \mathrm{SO}_{4}$ dan pemanasan $200^{\circ} \mathrm{C}$ ), dengan suhu operasi $118-667^{\circ} \mathrm{C}$. Gas ammonia yang keluar dari proses degassing pada rentang suhu tersebut di analisis langsung menggunakan Gas Cromatography (GC) 
dengan detektor jenis Thermal Conductivity Detector (TCD).

\section{Analisis produk hasil reaksi}

Untuk menentukan besarnya konversi gliserol yang dihasilkan, analisis hasil reaksi dilakukan dengan metode titrasi iodometri menggunakan titran $0,01 \mathrm{~N}$ sodium thiosulfat baik pada gliserol awal (Go) maupun gliserol sisa (Gs). Besarnya konversi gliserol yang dihasilkan dihitung dengan persamaan:

$$
X_{G}=\frac{G_{0}-G_{s}}{G_{0}} \times 100 \%
$$

dengan,

$\mathrm{X}_{\mathrm{G}} \quad=$ konversi gliserol, $\%$

$\mathrm{G}_{\mathrm{o}}$ dan $\mathrm{G}_{\mathrm{s}}=$ gliserol awal dan gliserol sisa, $\%$

Pada kondisi terbaiknya dilakukan analisis menggunakan kromatografi gas (GC) guna mengetahui persentase produk solketal yang terbentuk dari reaksi ketalisasi yang terjadi. GC yang digunakan adalah GC Hewlett Packard 5890 Series II dengan jenis kolom hp-1 dan detektor FID $300^{\circ} \mathrm{C}$. Kondisi operasi GC dilakukan pada suhu injektor $290^{\circ} \mathrm{C}$ dengan injeksi sampel sebanyak $0,5 \mu \mathrm{L}$, laju carier helium sebesar $50 \mathrm{ml} / \mathrm{menit}$, dan suhu oven dioperasikan pada rentang $50-280^{\circ} \mathrm{C}$. Suhu oven ditingkatkan secara bertahap dari suhu awal $50^{\circ} \mathrm{C}$ dan secara perlahan dinaikkan dengan kecepatan $10^{\circ} \mathrm{C}$ menit sampai suhu akhir $280^{\circ} \mathrm{C}$.

\section{HASIL DAN PEMBAHASAN \\ Pengaruh Perlakuan awal Terhadap Kekuatan Asam dan Daya Protonasi ZAB}

Hasil pengukuran TPD ammonia yang disajikan pada Gambar 3 memperlihatkan bahwa zeolit alam Bayah (ZAB) tanpa pengasaman, menghasilkan satu puncak saja yaitu pada suhu $213,2^{\circ} \mathrm{C}$. Pada pengasaman $6 \mathrm{~N} \mathrm{H}_{2} \mathrm{SO}_{4}$ terdapat dua puncak, yaitu puncak pertama muncul pada suhu $209,9^{\circ} \mathrm{C}$ dan puncak kedua muncul pada suhu $501,5^{\circ} \mathrm{C}$. Hasil analisis TCD tersebut mengindikasikan bahwa kekuatan asam pada zeolit alam Bayah dengan pengasaman $6 \mathrm{~N}_{2} \mathrm{H}_{2} \mathrm{SO}_{4}$ dan pemanasan $200^{\circ} \mathrm{C}$ mempunyai kekuatan asam yang lebih besar dibandingkan dengan zeolit alam Bayah tanpa pengasaman, karena zeolit yang mempunyai puncak high temperature akan mempunyai kekuatan asam yang lebih besar dibandingkan zeolit yang mempunyai low temperature (Sang dkk., 2004). Hal ini terjadi karena ikatan antara situs aktif yang terdapat pada zeolit tanpa pengasaman dan ammonia yang lemah, menyebabkan ammonia mudah terlepas ketika dipanaskan pada suhu operasi yang relatif rendah.Untuk ZAB dengan perlakuan awal (pengasaman $6 \quad \mathrm{~N}_{2} \mathrm{H}_{2} \mathrm{SO}_{4}$ dan pemanasan $200^{\circ} \mathrm{C}$ ) puncak kedua yang muncul dari proses pemanasan lanjut pada TPD yang mencapai suhu $501,5^{\circ} \mathrm{C}$ menjadi bukti bahwa ikatan antara ammonia dan situs aktif ZAB cukup kuat, karena untuk melepaskan ikatan tersebut butuh suhu yang lebih tinggi.

Hasil karakteristik yang dilakukan oleh Nuryoto dkk. (2016) pada percobaan yang berbeda yaitu pada modifikasizeolit alam mordenit sebagai katalisator ketalisasi dan esterifikasi, ZAB tanpa perlakuan awal (ZAB segar) dan $\mathrm{ZAB}$ dengan perlakuan awal melalui pengasaman $6 \mathrm{~N} \mathrm{H}_{2} \mathrm{SO}_{4}$ dan pemanasan $200^{\circ} \mathrm{C}$ menunjukkan bahwa terjadi peningkatan rasio $\mathrm{SiO}_{2} / \mathrm{Al}_{2} \mathrm{O}_{3}$ dan luas permukaan yaitu masing-masing 6,78 dan $55,54 \mathrm{~m}^{2} / \mathrm{g}$ untuk ZAB tanpa perlakuan awal dan 9,16 dan $149,31 \mathrm{~m}^{2} / \mathrm{g}$ untuk ZAB dengan perlakuan awal. Hal ini terjadi karena pengasaman dan pemanasan yang dilakukan akan menyebabkan terjadinya proses dealuminasi yang dikuti tereduksinya pengotor alkali pada zeolit, serta teruapnya air yang terjebak pada alur-alur zeolit akibat pemanasan. Peningkatan rasio $\mathrm{SiO}_{2} / \mathrm{Al}_{2} \mathrm{O}_{3}$ akan berimbas pada peningkatan BrÖnsted acid sites pada zeolit, dan hal ini yang menyebabkan kekuatanasam dari zeolit mengalami peningkatan (Marschmeyer

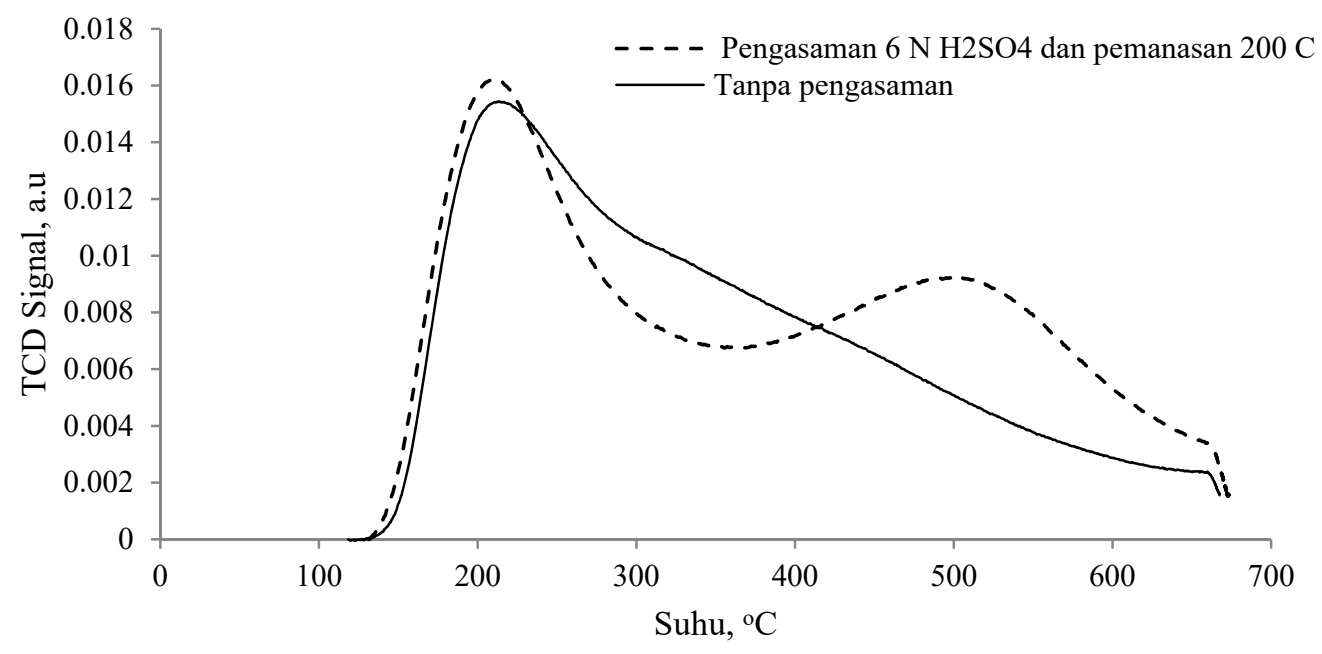

Gambar 3. Hasil analisis TPD ammonia katalisator ZAB 
dan Papp, 1997; Zhichun dkk., 2010). Semakin kuat keasaman situs aktif dari suatu katalisator zeolit, maka daya protonasi yang dimiliki katalisator tersebut akan semakin besar, dan mampu memicu terjadinya reaksi menjadi lebih maksimal (Triantafillidis dan Evmiridis, 1999; Greatbanks dkk., 1996). Hasil analisis TPD pada penelitian ini (Gambar 3) selaras dengan hasil uji coba yang dilakukan oleh Aboul dan Geit (1991) pada zeolit Y. Peningkatan rasio $\mathrm{SiO}_{2} / \mathrm{Al}_{2} \mathrm{O}_{3}$ pada zeolit $\mathrm{Y}$ diikuti dengan peningkatan kekuatan asam dari zeolit tersebut. Peak atau puncak kedua muncul pada suhu berturut-turut adalah $341 ; 390$; dan $423^{\circ} \mathrm{C}$ untuk rasio $\mathrm{SiO}_{2} / \mathrm{Al}_{2} \mathrm{O}_{3} 4,8 ; 6,6$; dan 8,5 . Hasil observasi yang dilakukan dalam rangka menguji daya protonasi dan unjuk kerja dari katalisator ZAB tersaji pada Gambar 4.

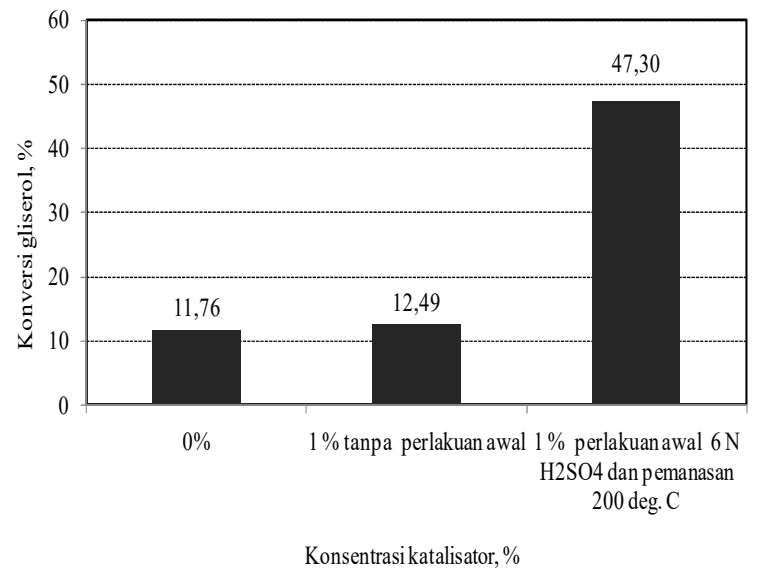

Gambar 4. Konversi gliserol hasil uji coba dampak dari kekuatan asam pada ukuran katalisator $-40+45$ mesh

Pada Gambar 4 terlihat bahwa konversi gliserol tertinggi dihasilkan pada katalisator ZAB dengan konsentrasi $1 \%$ massa gliserol dengan perlakuan awalmenggunakan $6 \mathrm{~N} \mathrm{H}_{2} \mathrm{SO}_{4}$ dan pemanasan $200^{\circ} \mathrm{C}$, yaitu dengan capaian konversi gliserol yang diperoleh sebesar 47,30\%. Hasil tersebut memberikan indikasi bahwa katalisator ZAB yang telah dilakukan perlakuan awal mempunyai performa yang lebih baik dibandingkan ZAB tanpa perlakuan awal, dan perlakuan awal tersebut berpengaruh besar dalam meningkatkan daya protonasi katalisator ZAB tersebut ke reaktan yang bereaksi.

\section{Pengaruh Ukuran Katalisator}

Hasil investigasi pengaruh ukuran katalisator ZAB terhadap laju reaksi ketalisasi gliserol dan asetontersaji pada Gambar 5.

Pada ukuran katalisator $-18+25$ ke $-40+45$ mesh, konversi gliserol yang dihasilkan mengalami peningkatan yang cukup berarti yaitu dari 27,41\% menjadi 57,89\% (lihat Gambar 5). Sebaliknya, ketika ukuran katalisator diperkecil di bawah -40+45 mesh, justru terjadi penurunan konversi gliserol yang dihasilkan yaitu dari $53,40 \%$ pada $-45+60$ mesh menjadi 51,85\% pada $-60+70$ mesh. Padahal secara teoritis laju perpindahan massa internal berbanding terbalik dengan delta jari-jari dari katalisator, sehingga semakin kecil ukuran diameter katalisator, maka semakin besar laju perpindahan massa internal yang dihasilkan (Bird dkk., 2002), dan memungkinan kontak antar reaktan pada sisi aktif katalisator semakin besar. Penurunan konversi gliserol yang terjadi, khususnya untuk ukuran katalisator di bawah $-40+50$ mesh(-45+60 mesh dan -60+70 mesh)kemungkinan besar akibat dari terjadinya stagnansi dari katalisator, yaitu katalisator mengikuti arah gerakan dari fluida akibat dari tingginya kecepatan pengadukan yang dilakukan (Fogler, 2006). Secara visual ketika reaksi berlangsung terlihat gerakan zeig-zag dari katalisator ZAB di bawah $-40+50$ mesh lebih pelan dibandingkan pada ukuran katalisator $-40+50$ mesh. Kondisi ini memicu turbulensi (bilangan Reynold) dari katalisator akan mengalami penurunan, sehingga pengaruh yang ditimbulkan adalah laju perpindahan massa internal ke sisi aktif katalisator menjadi sangat kecil (Bird dkk., 2002). Fenomena serupa juga dialami pada percobaan pembuatan butil asetat dari asam asetat dan butanol yang dilakukan oleh Gangadwala dkk. (2003). Pembuatan butil asetat yang dilakukan dengan menggunakan katalisator amberyst-15 pada kecepatan pengadukan $1000 \mathrm{rpm}$ dan ukuran mesh 25-100 mesh, konversi asam asetat tertinggi dicapai justru pada ukuran katalisator 25 mesh yaitu sebesar 58\%. Konversi asam asetat cenderung mengalami penurunan ketika ukuran katalisator diperkecil menjadi 100 mesh yaitu dengan capaian konversi asam asetat menjadi $52 \%$.

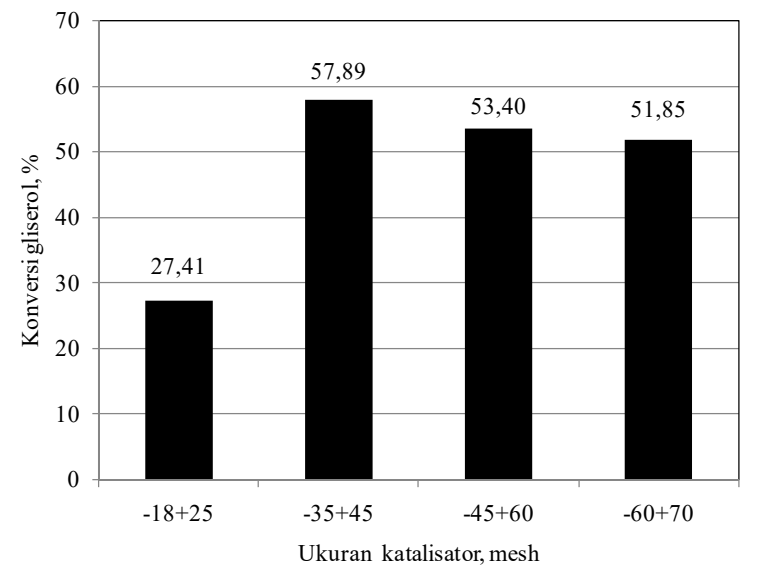

Gambar 5. Konversi gliserol pada pelbagai ukuran diameter katalisator pada kecepatan pengadukan 600 rpm dan konsentrasi katalisator 5\% massa gliserol

\section{Pengaruh Konsentrasi Katalisator}

Investigasi pengaruh dari variabel konsentrasi katalisator terhadap peningkatan konversi gliserol tersaji pada Gambar 6. 


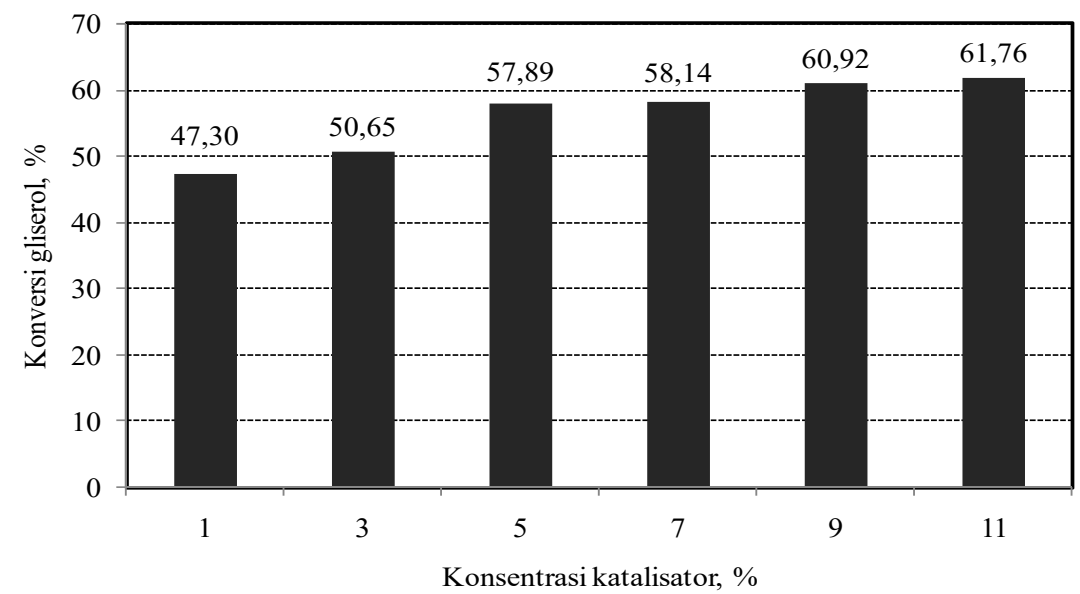

Gambar 6. Konversi gliserol pada pelbagai konsentrasi katalisator pada kecepatan pengadukan 600 rpm dan ukuran katalisator $-40+45$ mesh

Seiring meningkatnya konsentrasi katalisator, diikuti dengan meningkatnya konversi gliserol yang dihasilkan (lihat Gambar 6). Konversi gliserol pada konsentrasi katalisator $1 ; 3 ; 5 ; 7$; 9; dan $11 \%$ berturutturut adalah 47,30;50,65;57,89;58,14;60,92; dan $61,76 \%$. Jika diamati lebih lanjut, pada rentang konsentrasi katalisator 1-5\% massa gliserol, konversi gliserol yang dihasilkan menunjukan peningkatan yang cukup baik. Peningkatan konsentrasi katalisator dari $1 \mathrm{ke} 3 \%$ massa gliserol mampu meningkatkan konversi gliserol sebesar 3,35\% (meningkat dari 47,30 menjadi 50,65\%), dan konsetrasi katalisator dari 3 ke $5 \%$ massa gliserol konversi gliserol meningkat sebesar 7,24\% (meningkat dari 50,65 menjadi 57,89\%). Sebaliknya, pada saat konsentrasi katalisator dinaikkan di atas 5\% massa gliserol konversi gliserol yang dihasilkan hanya meningkat rerata di bawah $2 \%$. Hasil pengamatan secara visual pada saat reaksi berlangsung memperlihatkan bahwa pada rentang konsentrasi katalisator 7-11\% massa gliserol terjadi dead zone, yang mana ada sebagian katalisator yang tidak bergerak dan diam pada tepi dan bagian bawah reaktor. Dead zone menyebabkan turbulensi katalisator menjadi terganggu, sehingga penambahan katalisator pada sistem reaksi tidak memberikan pengaruh besar terhadap proses reaksi kimia yang terjadi. Hasil serupa juga dialami oleh Ali dan Merchant (2009) pada studi kinetika esterifikasi menggunakan katalisator Dowex 50 dan hidrolisis benzil asetat dengan rentang konsentrasi katalisator 10-60 gram/liter, dan kecepatan pengadukan $900 \mathrm{rpm}$. Pada konsentrasi katalisator dari 10 ke 30 gram/liter, konversi asetat asetat mengalami peningkatan yang cukup signifikan yaitu sebesar 15,6\% (meningkat dari 37,9 menjadi 53,5\%). Ketika konsentrasi katalisator ditingkatkan kembali dari 30 ke 50 gram/liter, peningkatan konversi asam asetat yang dihasilkan hanya meningkat sebesar 4,2\% (meningkat dari 53,5 menjadi 57,7\%), dan kemudian konversi yang dihasilkan cenderung sama pada saat konsentrasi katalisator dinaikan lagi dari 50 ke 60 gram/liter. Jadi peningkatan konsentrasi katalisator pada sistem reaksi akan efektif terhadap peningkatan konversi reaktan yang dihasilkan ketika fenomena dead zone belum terjadi.

\section{Pengaruh Kecepatan Pengadukan}

Hasil observasi pengaruh kecepatan pengadukan yang dilakukan pada rentang 200-800 rpm tersaji pada Gambar 7.

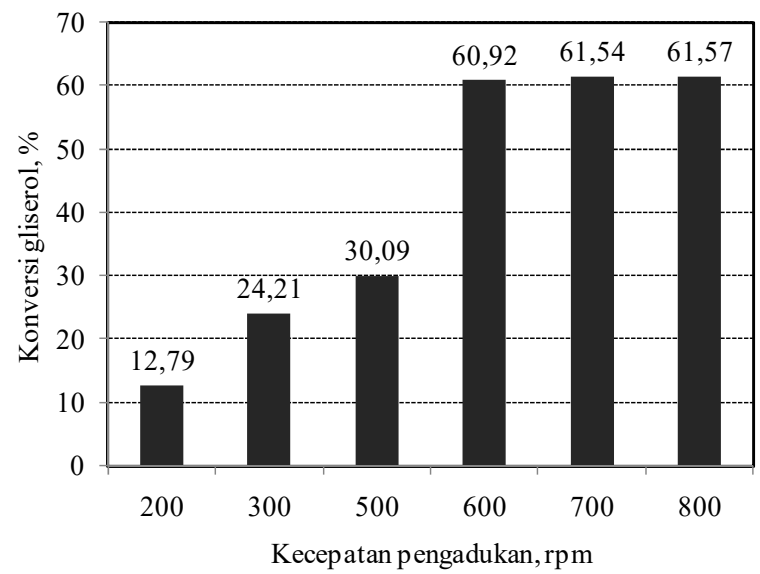

Gambar 7. Konversi gliserol pada pelbagai kecepatan pengadukan pada ukuran katalisator- $40+45$ mesh, dan konsentrasi katalisator 9\% massa gliserol

Pada rentang 200 sampai 600 rpm, peningkatan kecepatan pengadukan yang dilakukan berdampak signifikan terhadap peningkatan konversi gliserol yang dihasilkan yaitu berturut-turut 12,$79 ; 24,2 ; 30,09$ dan $60,09 \%$ untuk 200; 300; 500; dan 600 rpm (lihat Gambar 7). Peningkatan konversi gliserol terbesar terjadi pada kecepatan pengadukan dari 500 ke 600 rpm yaitu meningkat dari 30,09 menjadi 60,92\% (naik lebih dari 100\%). Hasil tersebut mengindikasikan bahwa peningkatan kecepatan pengadukan 500 ke $600 \mathrm{rpm}$ mampu mereduksi tahanan perpindahan massa eksternal yang cukup 
besar, sehingga proses perpindahan massa reaktan ke permukaan aktif katalisator dan proses reaksi dapat berjalan dengan baik. Hasil yang berbeda diperoleh ketika kecepatan pengadukan dinaikkan di atas 600 rpm konversi gliserol yang dihasilkan cenderung sama, yaitu hanya meningkat kurang dari 1\% tiap peningkatan $100 \mathrm{rpm}(60,92 \%$ untuk $600 \mathrm{rpm}, 61,54 \%$ untuk $700 \mathrm{rpm}$, dan $61,57 \%$ untuk $800 \mathrm{rpm})$. Ini artinya bahwa tahanan perpindahan massa eksternal pada 600 rpm sebenarnya sudah sangat kecil, sehingga peningkatan pengadukan di atas $600 \mathrm{rpm}$ tidak lagi berpengaruh besar terhadap konversi gliserol yang dihasilkan. Pada percobaanesterifikasi dan hidrolisis benzil asetat oleh Ali dan Merchant (2009) mempunyai kecenderungan yang serupa dengan hasil percobaan pada Gambar 7. Percobaan yang dilakukan pada rentang pengadukan 100-700 rpm,konversi asam asetat yang dihasilkan menunjukkan perbedaan yang cukup signifikan yaitu $9 ; 15 ; 40$; dan $50 \%$ untuk kecepatan pengadukan masing-masing $100 ; 300 ; 500$; dan $700 \mathrm{rpm}$. Pada saat kecepatan pengadukan dinaikan di atas $700 \mathrm{rpm}$, tidak memberikan dampak yang berarti terhadap perubahan konversi asam asetat yang dihasilkan, yaitu hanya meningkat masingmasing sebesar $1 \%$.

\section{Pengujian Solketal}

Pada reaksi ketalisasi gliserol dengan aseton, solketal merupakan produk utama reaksi. Guna mengetahui ada tidaknya produk solketal hasil reaksi pada penelitian ini, maka dipandang perlu untuk melakukan analisis sampel hasil reaksi menggunakan gas cromatography (GC). Gambar 8 merupakan hasil analisis GC yang dilakukan pada kondisi terbaiknya yaitu pada konsentrasi katalisator 9\% massa gliserol, kecepatan pengadukan $600 \mathrm{rpm}$, dan ukuran katalisator $-40+45$ mesh.

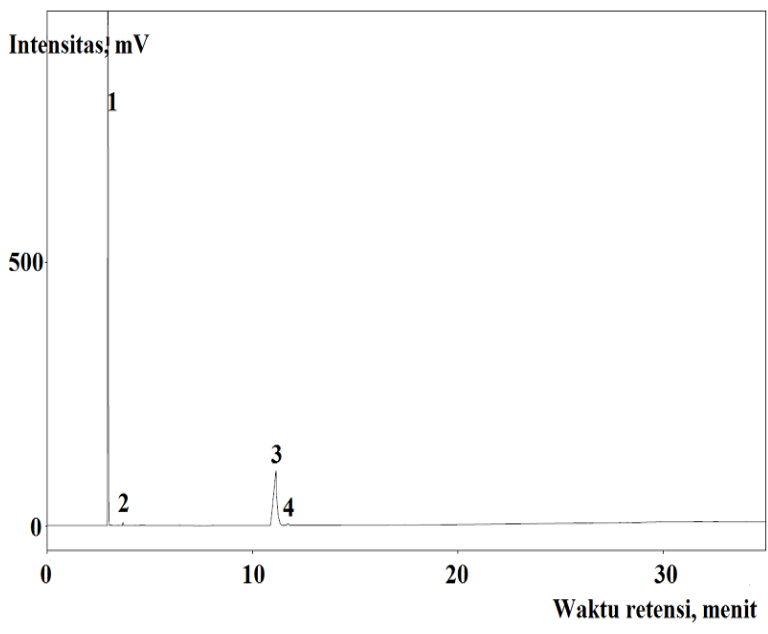

Gambar 8. Hasil analisis GC hasil reaksi pada

konsentrasi katalisator 9\% massa gliserol, kecepatan pengadukan $600 \mathrm{rpm}$, dan ukuran katalisator

$$
-40+45 \text { mesh }
$$

Indentifikasi produk solketal pada Gambar 8 dilakukan dengan membandingkan kromatogram hasil analisis GC pada sampel dan kromatogram pada sampel yang diinjeksikan standar solketal seperti yang dilakukan pada penelitian Nuryoto dkk. (2016) mengenai sintesis bioaditif menggunakan katalisator indion $225 \mathrm{Na}$. Peak atau puncak yang mempunyai kemiripan dengan penelitian sebelumnya (Nuryoto dkk., 2016) adalah peak no 3, sehingga dapat dipastikan bahwa peak no 3 adalah solketal. Hasil peak report pada peak no 3 menunjukan bahwa secara relatif kadar solketalsebesar 29,99\%, sehingga yield solketal yang dihasilkan sebesar 49,23\%. Mengacu pada konversi gliserol dan yield solketal yang dihasilkan tersebut, katalisator ZAB layak untuk dikembangkan lebih lanjut dan dapat dijadikan sebagai katalisator alternatif pada ketalisasi gliserol.

\section{KESIMPULAN}

Rekayasa proses dalam rangka peningkatan unjuk kerja katalisator zeolit alam Bayah (ZAB) pada reaksi ketalisasi gliserol sebagai tindak lanjut dari penelitian sebelumnya (Nuryoto dkk., 2015) dengan meningkatkan parameter berpengaruh pada rentang tertentu, yaitu ukuran katalisator $-18+25$ sampai -60+70 mesh, kecepatan pengadukan 200-800 rpm, dan konsentrasi katalisator $0-11 \%$ menunjukan hasil yang positif. Konversi gliserol yang dihasilkan mengalami peningkatan 3,87\% (yaitu meningkat dari $57,89 \%$ menjadi $61,76 \%$ ), yang diperoleh pada kecepatan pengadukan $600 \mathrm{rpm}$, konsentrasi katalisator $11 \%$ massa gliserol, dan ukuran katalisator $-40+45$ mesh. Jika dilihat dari segi efisiensi penggunaan katalisator, kondisi terbaik sebenarnya diperoleh pada ukuran katalisator $-40+45$ mesh, dan konsentrasi katalisator $9 \%$ massa gliserol, dan kecepatan 600 rpm yaitu dengan konversi gliserol yang diperoleh sebesar $60,92 \%$.

\section{DAFTAR PUSTAKA}

Aboul, A.K. and Geit, (1991), Effect of Decationation and Dealumination of Zeolite Yon Its Acidity as Assessed by Ammonia Desorption Measured by Differential Scanning Calorimetry (DSC), Themochimica Acra Journal, (191), pp. 233-240.

Ali, H.S. and Merchant, S.Q., (2009), Kinetic Study of Dowex 50 Wx8-Catalyzed Esterification and Hydrolysis of Benzyl Acetate, Industrial \& Engineering Chemistry Research Journal, 48, pp. 2519-2532

Bird, B.B., Stewart, E.W., and Ligtfoot, E.N., (2002), Transport Phenomena, $2^{\text {nd }}$ Edition, John Wiley \&Sons, Inc, 605 Third avenue, New York, pp. 677681 .

Esteban, J., Ladero, M., and Ochoa, F.G., (2015), Kinetic Modelling of the Solventless Synthesis of 
Solketal with a Sulphonic Ion Exchange Resin, Chemical Engineering Journal, 269, pp. 194-202.

Fogler, S.H., (2006), Elements of Chemical Reaction Engineering, $4^{\text {th }}$ Edition Prentice Hall International Series, Upper Sadle River, New Jersey.

Gangadwala, J., Mankar, S., and Mahajani,S., (2003), Esterification of Acetic Acid with Butanol in the Presence of Ion-Exchange Resins as Catalysts, Industrial \& Engineering Chemistry Research Journal, 42, pp. 2146-2155.

Ginting, A.B., Anggraini, D., Indaryati, S., dan Kriswarini, R., (2007), Karakterisasi Komposisi Kimia,Luas Permukaan Pori, dan Sifat Termal dari Zeolit Bayah, Tasikmalaya, dan Lampung, Jurnal Teknologi Bahan Nuklir, 3(1), hal. 38-48

Greatbanks, S., Hillier, I.H., and Sherwood, P., (1996), Comparison of Embedded Cluster Models to Study Zeolite Catalysis: Proton Transfer Reactions in Acidic Chabazite, Journal of Computational Chemistry, 18(4), pp. 562-568.

Kolah, A., Asthana, N.S., Vu, D.T., Lira, C.T., and Miller, J., (2008), Reaction Kinetics for the Heterogeneously Catalyzed Esterification of Succinic Acid with Ethanol, Industrial and Engineering Chemistry Research Journal, 47, pp. 5313-5317.

Liu, T.W. and Tan, C.S., (2001), Liquid - Phase Esterification of Propionic Acid with n-Butanol, Industrial and Engineering Chemistry Research Journal, 40, pp. 3281-3286.

Mallesham, B., Sudarsanam, P., and Reddy, B.M., (2014), Eco-friendly Synthesis of Bio-AdditiveFuels from Renewable Glycerol Using Nanocrystalline $\mathrm{SnO}_{2}$-based Solid Acid, Catalysis Science \& Technology Journal, 4, pp. 803-813.

Manjunathan, P., Sanjeev, P. Maradur, A.B. Halgeri, Shanbhag G.V., (2014), Room Temperature Synthesis of Solketal from Acetalization of Glycerolwith Acetone: Effect of Crystallite Size and the Role of Acidity of Betazeolite, Journal of Molecular Catalysis A: Chemical, 36, pp.47-54.

Marschmeyer, S. and Papp, H., (1997), Surface Analysis of a Hydrithermally Treated H-ZSM-5 Zeolite, Surface and Interface Analysis, 25, pp. 660666.

Murpik, (2010), Zeolit Lebak, www.pelita.or.id
Nanda, M.R., Yuan, Z., Qin, W., Ghaziaskar, H.S., Poirier, M.A., and Xu, C.C., (2014), Thermodynamic and Kinetic Studies of a Catalytic Process to Convert Glycerol into Solketal as Anoxygenated Fuel Additive, Journal of Fuel, 117, pp. 470-477.

Nuryoto, Jayanudin, Fahlawan, H., Sulistyo, S., Sulistyo, H., dan Sediawan, W.B., (2012), Optimalisasi Kinerja Katalisator Padat Indion $225 \mathrm{Na}$ pada Proses Pembuatan Gliserol Karbonat, Prosiding Seminar Nasional Rekayasa Sains dan Teknologi, FT. Universitas Bung Hatta Padang.

Nuryoto, Sulistyo, H., Sediawan, W.B., and Perdana, I., (2015), Preliminary Study of Bayah Natural Zeolite as Catalyst at the Ketalization of Glycerol with Acetone, Proceeding $10^{\text {th }}$ International Forum on Strategic Technologi (IFOST), Fakultas Teknik UGM.

Nuryoto, Sulistyo, H., Sediawan, W.B., dan Perdana, I., (2016), Modifikasi Zeolit Alam Mordenit sebagai Katalisator Ketalisasi dan Esterifikasi, Reaktor, 16 (2), hal. $72-80$

Nuryoto, Sulistyo, H., Sediawan, W.B., dan Perdana, I., (2016), Sintesis Bioaditif Gasoline Melalui Ketalisasi Gliserol Menggunakan Katalisator Padat, Jurnal Bahan Alam Terbarukan, 5(2), hal. 74-83.

Reddy, P.S., Sudarsanam, P., Mallesham, B., Raju, G., and Reddy, B.M., (2011), Acetalisation of Glycerol with Acetone over Zirconia and Promoted Zirconia Catalysts under Mild Reaction Conditions, Industrial and Engineering Chemistry Research Journal, 17, pp. 377-381.

Sang, S., Chang, F., Liu, Z., He, C., He, Y., and Xu, L., (2004), Difference of ZSM-5 zeolites synthesized with various template, Catalysis Today, 93-95, pp. 729-734

Suminta, S. dan Las, T., (2006), Penghalusan Struktur Sangkar Kristal Modernit dan Klinoptilolit Alam dengan Metode Rietveld, Jurnal Sains Material Indonesia, (7)2, hal.73-78.

Triantafillidis, C.S. and Evmiridis, N.P., (1999), Performance of ZSM-5 as A Fluid Catalytic Cracking Catalyst Additive: Effect of the Total Number of Acid Sites and Particle Size, Industrial and Engineering Chemistry Research Journal, 38, pp. 916-927.

Zhichun, S., Duan, W., Xiaodong, W., and Yang, J., (2010), Roles of Lewis and Brønsted Acid Sites in NO Reduction with Ammonia on $\mathrm{CeO}_{2}-\mathrm{ZrO}_{2}-\mathrm{NiO}-\mathrm{SO}_{4}{ }^{2-}$ Catalyst, Journal of Rare Earths, (28) 5, pp. 727-731 